Hal : $34-39$

\title{
ANALISIS RESPON SISWA TERHADAP PERTANYAAN GURU DITINJAU DARI POLA ASUH ORANG TUA
}

\author{
Nurhaty Purnama Sari ${ }^{1{ }^{*},}$, Wilda Fasim Hasibuan ${ }^{2}$ \\ ${ }^{1}$ Pendidikan Biologi Fakultas Pendidikan dan IImu Keguruan Universitas Riau Kepulauan \\ Jalan Batu Aji Baru No.99 Kec.Batu Aji-Kota Batamnurhatypurnamasari@gmail.com \\ ${ }^{2}$ Bimbingan Konseling Fakultas Pendidikan dan IImu Keguruan Universitas Riau Kepulauan \\ Jalan Batu Aji Baru No.99 Kec.Batu Aji-Kota Batamwida@fkip.unrika.ac.id
}

Diterima September 2018, Disetujui Desember 2018

\begin{abstract}
ABSTRAK
Penelitian ini bertujuan untuk mengetahui respon siswa kelas 4 terhadap pertanyaan guru dalam proses pembelajaran sains dengan menggunakan media tumbuhan Hidup di SD Negeri 008 Batam Kota. Hasil dari penelitian ini menunjukkan respon siswa pada pertanyaan guru yang didominasi $\mathrm{C} 1$ (menghafal) dan $\mathrm{C} 2$ (memahami) yaitu menjawab dengan jawaban ilmiah $(92.31 \%)$, menjawab serentak $(77.50 \%)$, dan 4 orang siswa yang bertanya kepada guru dari 40 siswa. Ditemukan juga 7,5\% siswa dengan pola asuh permisif, 22,5\% siswa dengan gaya pengasuhan demokrasi dan $70 \%$ dengan tipe pola asuh otoriter.
\end{abstract}

Kata kunci: respon, pertanyaan, sains,tumbuhan, pola asuh, orang tua, gaya pengasuhan

\section{PENDAHULUAN}

Dalam Undang-undang Sistem PendidikanNasional No.20 Tahun 2003 Bab II Pasal 3 menyatakan bahwa pendidikan adalah usaha sadar dan terencana untuk mewujudkan proses pembelajaran yang mendorong siswa secara aktif mengembangkan potensi agar menjadi manusia yang beriman dan bertakwa kepada Tuhan Yang Maha Esa, berakhlak mulia, sehat, berilmu, cakap, kreatif, mandiri, dan menjadi warga negara yang demokratis serta bertanggung jawab (Kusuma, Candramila, \& Ariyati, 2017).

Pada proses pembelajaran yang menarik membuat siswa lebih senang dan mudah menyerap ilmu yang terlihat dari respon siswa selama proses pembelajaran. Menurut Kamus Besar Bahasa Indonesia, respon berarti reaksi atau tanggapan berupa penerimaan, penolakan, atau sikap acuh tak acuh terhadap apa yang disampaikan oleh komunikator dalam pesannya (Poerwadarminta, 2003) dalam (Kusuma et al., 2017).

Namun sikap siswa biasanya juga banyak dipengaruhi berbagai factor, salah satunya adalah latar belakang keluarga, tingkat social ekonomi, dan keberhasilan akademik siswa. Selain itu, ada satu factor yang tidak kalah pentingnya adalah pola asuh orang tua, dalam beberapa penelitian sebelumnya ada kaitan yang sangat rumit antara pola asuh orang tua dengan perilaku yang ditampilkan siswa baik dalam pembelajaran maupun dalam bersosialisasi (Doinita \& Maria, 2015; Jahan \& Suri, 2016).

Dari uraian diatas menunjukkan bahwa keberhasilan suatu proses pembelajaran yang disajikan oleh guru adalah dilihat dari respon, perkembangan siswa dan pola asuh orang tua. Untuk melihat hal tersebut guru pada umumnya memberikan pertanyaan kepada siswa untuk melihat sejauh mana penguasaan siswa terhadap materi. Pertanyaan yang diberikan oleh guru biasanya disajikan pada saat proses pembelajaran maupun pada saat evaluasi. Oleh karena itu kami ingin meneliti sejauh mana respon siswa pada pertanyaan guru ditinjau dari pola asuh orang tua.

\section{METODE}

Pendekatan yang digunakan adalah metode kombinasi yang dapat digambarkan sebagai berikut: analisis proses respon siswa terhadap pertanyaan guru menggunakan metode kualitatif dengan 
Hal : $34-39$

pendekatan deskriptif, sedangkan analisis pola asuh orang tua menggunakan skala terpakai yang diambil dari penelitian sebelumnya. (Robinson, Mandleco, Olsen, \& Hart, 1995).

Pengambilan data dengan
menggunakan wawancara, observasi, dokumentasi dan skala pola asuh orang tua. Analisis data untuk menjawab pertanyaan penelitian dilakukan dengan menggunakan pendekatan deskriptif, statistik deskriptif berupa rata-rata, atau persentase, yang kemudian diuraikan.

\section{HASIL DAN PEMBAHASAN \\ Hasil}

Dari hasil penelitian ditemukan 38 pertanyaan yang disampaikan guru kepada siswa. Kemudian setelah digolongkan ke dalam Taksonomi Bloom terbagi ke beberapa tingkatan seperti yang terdapat pada Tabel 1. Adapun topik yang ditanyakan oleh guru dalam pokok bahasan Bagian-Bagian Tumbuhan dan Fungsinya pada masing-masing tingkat pertanyaan guru berdasarkan Taksonomi Bloom dapat dilihat pada tabel 1.

Tabel 1. Persentase Tingkat Pertanyaan lisan Guru SMP Kabupaten Deliserdang Berdasarkan Taksonomi Bloom

\begin{tabular}{ccc}
\hline $\begin{array}{c}\text { Tingkat } \\
\text { pertanyaan }\end{array}$ & Frekuensi & $\begin{array}{c}\text { Persentase } \\
(\%)\end{array}$ \\
\hline C1 & 14 & $36.84 \%$ \\
C2 & 24 & $63.16 \%$ \\
C3 & 0 & $0.00 \%$ \\
C4 & 0 & $0.00 \%$ \\
C5 & 0 & $0.00 \%$ \\
C6 & 0 & $0.00 \%$ \\
\hline Jumlah & $\mathbf{3 8}$ & $\mathbf{1 0 0 . 0 0 \%}$ \\
\hline
\end{tabular}

Pada pokok bahasan Bagian-Bagian Tumbuhan dan Fungsinya yang terdiri dari dua subpokok bahasan yaitu 1) Tumbuhan dan bagian-bagiannya; dan 2) Kegunaan tumbuhan. Guru lebih dominan menanyakan sub pokok bahasan tumbuhan dan bagian-bagiannya. Dari ungkapan pertanyaan yang disampaikan oleh guru terlihat bahwa guru lebih dominan bertanya di tingkat C2 dengan kategori dominan memberikan contoh (exemplifying)mengkelasifikasikan (classifying), meringkas (summarizing), dan menjelaskan (explaining). Sedangkan C1 mencakup mengenali (recognizing) dan mengingat (recalling).

Respon yang dilihat dari siswa yaitu kategori jawaban siswa (ilmiah, setengah ilmiah, miskonsepsi, nol dan salah), siswa tidak bisa menjawab (pada saat guru bertanya kepada seluruh siswa), siswa memberi jawaban serentak, siswa yang ditunjuk namun tidak mampu menjawab, siswa yang ditunjuk mampu menjawab, siswa bingung untuk memberikan jawaban yang tepat siswa unjuk diri untuk menjawab pertanyaan, dan siswa yang bertanya guru. Adapun respon siswa dalam menjawab pertanyaan guru secara ilmiah, setengah ilmiah, miskonsepsi, nol dan salah terdapat pada tabel 2. Pada tabel 2 tersebut ditemukan pertanyaan guru tingkat $\mathrm{C} 1$ dan $\mathrm{C} 2$ dengan respon sebanyak 39 dari 38 pertanyaan, rata-rata dijawab dengan jawaban ilmiah dan sedikit setengah ilmiah dan nol, serta tidak ditemukan jawaban miskonsepsi ataupun salah. Adapun untuk tabel 3 diuraikan sebanyak 40 respon siswa dari 38 pertanyaan guru di jawab siswadengani jawaban serentak, siswa yang ditunjuk namun tidak mampu menjawab, siswa yang ditunjuk mampu menjawab, siswa bingung untuk memberikan jawaban yang tepat dan siswa unjuk diri untuk menjawab pertanyaan. 
Vol. 5, No. 2, Desember 2018

Hal : $34-39$

Tabel 2. Persentase Respon Siswa Terhadap Tingkat Pertanyaan Guru pada Tingkatan Taksonomi Bloom

\begin{tabular}{cccccc}
\hline $\begin{array}{c}\text { Tingkat } \\
\text { Pertanyaan }\end{array}$ & IImiah & $\begin{array}{c}\text { Setengah } \\
\text { Ilmiah }\end{array}$ & Miskonsepsi & Nol & $\begin{array}{c}\text { Salah } \\
(-)\end{array}$ \\
\hline C1 & 12 & 1 & 0 & 2 & 0 \\
C2 & 24 & 0 & 0 & 0 & 0 \\
C3 & 0 & 0 & 0 & 0 & 0 \\
C4 & 0 & 0 & 0 & 0 & 0 \\
C5 & 0 & 0 & 0 & 0 & 0 \\
C6 & 0 & 0 & 0 & 0 & 0 \\
\hline Jumlah & 36 & 1 & 0 & 2 & 0 \\
\hline Persentase & $92.31 \%$ & $2.56 \%$ & $0.00 \%$ & $5.13 \%$ & $0.00 \%$ \\
\hline
\end{tabular}

(a)

\begin{tabular}{ccccc}
\hline $\begin{array}{c}\text { Tingkat } \\
\text { Pertanyaan }\end{array}$ & Serentak & Unjuk diri & $\begin{array}{c}\text { Jawaban Siswa } \\
\text { Bingung/diam }\end{array}$ & $\begin{array}{c}\text { Ditunjuk tidak } \\
\text { mampu menjawab }\end{array}$ \\
\hline C1 & 12 & 2 & 0 & 0 \\
C2 & 19 & 5 & 1 & 1 \\
C3 & 0 & 0 & 0 & 0 \\
C4 & 0 & 0 & 0 & 0 \\
C5 & 0 & 0 & 0 & 0 \\
C6 & 0 & 0 & 0 & 0 \\
\hline Jumlah & 31 & 7 & 1 & 1 \\
\hline Persentase & $77.50 \%$ & $17.50 \%$ & $2.50 \%$ & $2.50 \%$ \\
\hline
\end{tabular}

(b)

Dari penelitian ini juga ditemukan siswa SD kelas 4 di SD Batam Kota yang bertanya kepada guru (tabel 3.3), terlihat pertanyaan mereka keseluruhan pada tingkat pertanyaan C1 (rendah) yaitu kebanyakan pemahaman konsep yang menanyakan nama ilmiah.
Sedangkan dari skala pola asuh orang tua yang diberikan kepada 40 orang siswa, didapati 3 orang siswa yang pola asuh orang tua permisif, 9 orang siswa dengan gaya pengasuhan demokrasi dan 28 siswa dengan pola asuh otoriter. Sementara didapat persentase dalam statistic, $7,5 \%$ siswa dengan pola asuh permisif, 22,5 \% siswa dengan gaya pengasuhan demokrasi dan $70 \%$ dengan tipe pola asuh otoriter. 
Vol. 5, No. 2, Desember 2018

Hal : $34-39$

Tabel 3. Respon siswa memberikan pertanyaan kepada guru

\begin{tabular}{|c|c|c|}
\hline No & Pertanyaan Siswa & $\begin{array}{c}\text { Tingkat } \\
\text { Pertanyaan }\end{array}$ \\
\hline 1 & Siswa D: “ organ dasar itu apa bu?” & $\mathrm{C} 1$ \\
\hline 2 & $\begin{array}{l}\text { Siswa E: "cara membedakan antara } \\
\text { monokotil dan dikotil..." }\end{array}$ & C1 \\
\hline $\begin{array}{l}3 \\
4\end{array}$ & $\begin{array}{l}\text { Siswa F :"monokotil itu apa?" } \\
\text { Siswa E: "apa perbedaan } \\
\text { antara..antara ciri-cirinya klorofil?" }\end{array}$ & $\begin{array}{l}\text { C1 } \\
\text { C1 }\end{array}$ \\
\hline 5 & Siswa S: "stomata itu apa bu" & C1 \\
\hline
\end{tabular}

\section{PEMBAHASAN}

Dari tabel 2 terlihat bahwa pembelajaran pada pokok bahasan Bagian-Bagian Tumbuhan dan Fungsinya dengan media tumbuhan hidup memberikan respon siswa yaitu sudah mampu memberikan jawaban ilmiah, pemberian jawaban dan didominasi dengan jawaban serentak guru masih dalam tingkat tinggi. Hal ini tidak cukup membuktikan siswa sudah paham dengan penguasaan materi tersebut. Jawaban serentak memiliki arti bahwa siswa bersama-sama turut menjawab pertanyaan guru dan tidak memastikan apakah jika siswa ditanya satu persatu dapat menjawab hal ini. Hal yang disampaikan Wajnry (1992) dalam(Hamiloglu \& Temiz, 2012) menunjukkan bahwa sementara guru sering merencanakan pertanyaan mereka dalam hal konten pelajaran, mereka tampaknya kurang menekankan pada pertimbangan pertanyaan dalam hal tuntutan kognitif dan bahasa yang dilakukan pada pelajar. Hasil penelitian mengungkapkan bahwa jenis pertanyaan yang paling disukai adalah $\mathrm{Ya} /$ Tidak dan pertanyaan gaya pengambilanjawaban pendek yang keduanya menempatkan siswa dalam posisi pasif, pencari informasi-penerima di kelas. Jenisjenis pertanyaan ini tidak cukup menantang siswa untuk berpikir pada level yang lebih tinggi dari kapasitas kognitif mereka, tetapi mengarahkan mereka ke respon yang cepat dan terbatas secara kognitif.

Hal ini menunjukkan bahwa dengan proses pembelajaran dengan metode tanya jawab dengan menggunakan media tumbuhan hidup tidaklah cukup. Beberapa sumber belajar dan tambahan media seperti infocus, powerpoint, video diperlukan untuk menambah pengalaman siswa dalam proses pembelajaran. Hasil ini sejalan dengan temuan oleh (Price et al. 2003) dalam (Sapri \& Finch, 2009) yang menemukan bahwa selain mengajar dan belajar, fasilitas adalah faktor kedua yang penting dalam proses pembelajaran. Penelitian (Mcgowen, 2007) mengungkapkan bahwa alat bantu pengajaran adalah fasilitas yang paling penting untuk mempengaruhi prestasi akademik siswa. Disini dalam mengajarkan sains perlu diketahui bahwa Sains atau IImu Pengetahuan Alam (IPA) merupakan salah satu cabang ilmu yang pengkajiannya berfokus pada alam dan proses-proses yang ada di dalamnya. IPA atau sains berasal dari kata "natural science". Natural memiliki arti alamiah dan berhubungan dengan alam, sedangkan science artinya ilmu pengetahuan. Artinya, sains dipandang sebagai ilmu pengetahuan yang mempelajari tentang alam atau yang mempelajari peristiwa-peristiwa yang terjadi di alam (Bundu, 2006) dalam (Martini, 2014).

Perkembangannya ditandai oleh adanya kumpulan fakta, metode ilmiah dan sikap ilmiah. Aktivitas yang berkaitan dengan IPA tidak terlepas di dalam kehidupan sehari-hari, sehingga pembelajaran IPA adalah pembelajaran yang mempunyai hubungan erat dengan pengalaman sesungguhnya. Siswa didorong untuk menemukan dan mengkonstruksi sendiri pengetahuan yang ada di pikirannya melalui penggunaan KPS dan sikap ilmiah, sehingga siswa bukan 
hanya sekedar pengguna atau penghafal pengetahuan, melainkan sebagai penemu dan pemilik ilmu (Widodo dkk, 2014) dalam (Martini, 2014).

Berbicara soal penemu dan pemilik ilmu, menjadikan siswa berkeingintahuan yang tinggi dan ingin selalu berkreatifitas tidak lepas dari pola asuh yang didapatnya dari orang tua. Penelitian sebelumnya menemukan bahwa executive function yang dimanfaatkan dalam belajar diperoleh dari pola asuh orang tua yang stabil dan sesuai dengan fase perkembangan anak (Huang, Klein, \& Leung, 2016). Dimana dimensi pola asuh ada dua, yang pertama adalah responsiveness yang berfokus pada kebutuhan siswa atau anak akan kehangatan, dukungan dan kasih sayang dari orang tuanya. Sementara demandingness terpaku pada control dari orang tua sehingga anak lebih matang, bertanggung jawab, dan dapat mematuhi aturan yang ada di dalam keluarga maupun di masyarakat (Doinita \& Maria, 2015)

analisis $\begin{array}{ccc}\text { Kemudian } & \text { kaitannya } & \begin{array}{c}\text { dengan } \\ \text { jawaban }\end{array} \\ \text { siswa } & \text { terhadap }\end{array}$ pertanyaan guru pada mata pelajaran sains dengan menggunakan media tumbuhan hidup adalah bahwa jawaban-jawaban yang diberikan siswa secara serentak belum dapat memberikan kesimpulan bahwa semua siswa memahami. Ini sejalan dengan fungsi dari executive function yang sebagai pengelola dari proses higher cognitive process yang akan mengarahkan siswa dalam berperilaku sesuai dengan tujuan pembelajaran yang ingin dicapai (Hendrawan, 2013).

Fungsi executive function akan berjalan secara sempurna jika kedua dimensi dari pola asuh orang tua terdapat dalam gaya pengasuhan, namun dalam penelitian ini didapati lebih banyak siswa dengan pola asuh otoriter. Sehingga ada kesenjangan antara demandingness dan renponsiveness (Hendrawan, 2013; Nyarko, 2011)

\section{UCAPAN TERIMA KASIH}

Peneliti mengucapkan terimakasih kepada Kementrian Riset, Teknologi dan Pendidikan Tinggi Republik Indonesia yang telah mendanai penelitian ini sepenuhnya, segenap civitas akademika Fakultas
Keguruan dan IImu Pendidikan Universitas Riau Kepulauan, guru dan siswa-siswi Kelas 4 Sekolah Dasar Negeri Batam kota.

\section{DAFTAR PUSTAKA}

Doinita, N. E., \& Maria, N. D. (2015). Attachment and Parenting Styles. Procedia - Social and Behavioral Sciences, 203, 199-204. https://doi.org/10.1016/j.sbspro.2015. 08.282

Hamiloglu, K., \& Temiz, G. (2012). The impact of teacher questions on student learning in efl. Journal of Educational and Instructional Studies in the World of Educational and Instructional Studies in the World, 2(2), 1-8.

Hendrawan, D. (2013). Factors Affecting Letter Fluency Performance among Indonesian Undergraduate Students: A Short Report. Procedia - Social and Behavioral Sciences, 97, 266270.

https://doi.org/10.1016/j.sbspro.2013. 10.232

Huang, A. S., Klein, D. N., \& Leung, H.-C. (2016). Load-related brain activation predicts spatial working memory performance in youth aged 9-12 and is associated with executive function at earlier ages. Developmental Cognitive Neuroscience, 17, 1-9. https://doi.org/10.1016/j.dcn.2015.10. 007

Jahan, A., \& Suri, S. (2016). Parenting Style in Relation to Mental Health among Female Adolescents. Abnormal and Behavioural Psychology, 02(03). https://doi.org/10.4172/24720496.1000125

Kusuma, A. M., Candramila, W., \& Ariyati, E. (2017). Respon Siswa Terhadap Pembelajaran Berbasis Masalah Pada Materi Pencemaran Lingkungan Di Kelas X Sma. 
Hal : $34-39$

Martini, K. (2014). Respon Siswa Terhadap Model Experiential Learning Pada Materi Pencemaran Lingkungan dalam Meningkatkan Keterampilan Proses Sains Abstrak, 283-287.

Mcgowen, R. S. (2007). The Impact of School Facilities on Student Achievement, 30(December).

Nyarko, K. (2011). The influence of authoritative parenting style on adolescents' academic achievement. American Journal of Social and Management Sciences, 2(3), 278-
282.

https://doi.org/10.5251/ajsms.2011.2.3.278.

282

Robinson, C. C., Mandleco, B., Olsen, S. F., \& Hart, C. (1995). The Parenting Styles and Dimensions Quitionares (PSDQ). Psychological Reports, 77, 813-830.

Sapri, M., \& Finch, E. (2009). Factors That Influence Student's Level of Satisfaction With Regards To Higher Educational Facilities Services. Malaysian Journal of Real Estate, 4(1), 34-51. 